\title{
A VÉGZŐS TANÍTÓ SZAKOS HALLGATÓK KÜLSŐ SZAKMAI GYAKORLATÁRÓL
}

\author{
KIS JENÖNÉ KENESEI Éva \\ a Kaposvári Egyetem Csokonai Vitéz Mihály Pedagógia Főiskolai Karának \\ föiskolai docense \\ kenesei.eva@ke.hu
}

A tanulmány a tanitó szakos hallgatók külsö szakmai gyakorlatának tapasztalatai és a szakvezetők véleménye alapján összefoglalja azokat az elemeket, amelyek a külső gyakorlatot eredményessé teszik, s amelyeket feltétlenül meg kell örizni az új képzési rendszerben is.

A tanító alapszak megőrizte négyéves képzési idejét a magyar felsőoktatás többciklusú, lineáris képzési szerkezetű átalakulási folyamatában. Ennek megfelelően a korábbi képzés időkeretei csak részben alakultak át, figyelembe véve a szak fejlesztésében megfogalmazódott belső igényeket, a közoktatás elvárásait, a felsőoktatás innovációs folyamatainak, és a pedagógia mesterképzésnek való megfelelést. A szak új képzési és kimeneti követelményeiben (252/2004. /VII.30./ Korm. rendelet) a gyakorlati ismeretekhez rendelhető minimális kreditérték 40 , melyből az intézményen kívüli összefüggő gyakorlati képzésben minimálisan szerezhető kreditérték 12. A szakon az új képzés szerint tanuló hallgatók a 2008/2009-es tanévben harmad évfolyamosok. A jövő tanévi képzésükben kerül sor először az összefüggő külső szakmai gyakorlatukra. Mindezért fontosnak tartom, hogy egy 2007-es vizsgálat alapján tekintsük át azokat az eredményeket, amelyekre építve fogalmazhatjuk meg az új képzési programot.

\section{Gyakorlati képzés a régi rendszer szerint}

A tanító szakos hallgatók felkészítésében a korábbi képesítési követelmények alapján hangsúlyosan jelenik meg a gyakorlati képzés az elméleti képzés mellett. A 2007ben végző évfolyamnál a követelmények szerint a kományrendelet (77/2002. /IV.13./ Korm. rendelet) értelmében a hallgatók gyakorlati képzésére a 240 kreditből mintegy 34-58 kreditet kell fordítani. Ez a Kaposvári Egyetem Pedagógiai Főiskolai Karán 47 kredit. 
1. táblázat: A 2007-ben végző tanító szakos évfolyam gyakorlati képzésének óraés vizsgaterve

\begin{tabular}{|c|c|c|c|}
\hline \multicolumn{4}{|c|}{ Szakmai gyakorlat } \\
\hline $\begin{array}{l}\text { Gyakorlati képzési modul- } \\
\text { általános képzés }\end{array}$ & $\begin{array}{l}\text { Óraszám, } \\
\text { vizsgaforma }\end{array}$ & Kredit & $\begin{array}{l}\text { Javasolt } \\
\text { szemeszter }\end{array}$ \\
\hline Egyéni komplex pedagógiai gyakorlat 1. & 10 óra aí & - & 1. \\
\hline Egyéni komplex pedagógiai gyakorlat 2. & 10 óra maí & 1 & 2. \\
\hline Egyéni komplex pedagógiai gyakorlat 3. & 10 óra aí & - & 3. \\
\hline Egyéni komplex pedagógiai gyakorlat 4. & 10 óra maí & 1 & 4. \\
\hline Egyéni komplex pedagógiai gyakorlat 5. & 10 óra maí & 1 & 5. \\
\hline $\begin{array}{l}\text { Egyéni komplex pedagógiai gyakorlat } \\
\text { a tanév elején }\end{array}$ & 30 óra aí & - & 3.5 \\
\hline Egyéni tanítási gyakorlat 1. & 50 óra gyj & 3 & 6. \\
\hline Egyéni tanítási gyakorlat 2. & 50 óra gyj & 3 & 7. \\
\hline Csoportos tanítási gyakorlat 1. & 45 óra maí & 3 & 4. \\
\hline Csoportos tanítási gyakorlat 2. & 45 óra gy & 3 & 5. \\
\hline Csoportos tanítási gyakorlat 3. & 90 óra gyj & 6 & 6. \\
\hline $\begin{array}{l}\text { Összefüggő komplex külső szakmai } \\
\text { gyakorlat } 1 .\end{array}$ & 100 óra gyj & 7 & 7. \\
\hline $\begin{array}{l}\text { Összefüggő komplex külső szakmai } \\
\text { gyakorlat } 2 .\end{array}$ & 100 óra gyj & 7 & 8. \\
\hline Összesen & 560 óra & 35 kredit & \\
\hline \multicolumn{4}{|c|}{ Gyakorlati képzési modul-müveltségi terület } \\
\hline Egyéni tanítási gyakorlat 1. & 7 óra gyj & 1 & 6. \\
\hline Egyéni tanítási gyakorlat 2. & 8 óra gyj & 1 & 7. \\
\hline Csoportos tanítási gyakorlat 1. & 45 óra gyj & 3 & 6. \\
\hline Csoportos tanítási gyakorlat 2. & 45 óra gyj & 3 & 7. \\
\hline Összefüggő szakmai gyakorlat 1. & 20 óra gyj & 2 & 7. \\
\hline Összefüggő szakmai gyakorlat 2. & 20 óra gyj & 2 & 8. \\
\hline Összesen & 145 óra & 12 kredit & \\
\hline Szakmai gyakorlat-Mindösszesen & 705 óra & 47 kredit & \\
\hline
\end{tabular}

A tanítói képesítés feljogosít az iskolai oktatás 1-4. osztályában - az idegen nyelv kivételével - valamennyi müveltségi terület (tantárgy) oktatási-nevelési feladatainak az ellátására, valamint az 5-6. osztályban legalább egy (megnevezett) müveltségi területen az oktató-nevelő munkára (158/1994. /XI. 17./ Korm. rendelet). 
A négyéves képzés teljes ideje alatt a szakmai gyakorlat különböző területeken valósul meg. A követelményekben megfogalmazott elvárásokat csak ennek megfelelően lehet teljesíteni. A gyakorlati képzés magában foglalja a 6-12 éves gyermekek tanulásának irányításához, személyiségük fejlesztéséhez szükséges korszerű eljárások, módszerek gyakorlását iskolai környezetben. Fejleszti a speciális tanítói képességeket, technikai jártasságokat. A hallgatók hospitálásokon, csoportos és egyéni iskolai gyakorlatokon vesznek részt.

A hallgatók az összefüggő szakmai gyakorlat kivételével az egyetem gyakorló intézményében (Gyakorló Általános Iskola és Gimnázium) végzik a fenti stúdiumokat. Ennek több előnye van. Rendelkezésre áll egy magasan kvalifikált szakvezetői, pedagógusi kör, akik napi kapcsolatban vannak az elméleti képzést folytató oktatókkal. Így a hallgatók koherens képzésben részesülnek, az elméletben tanultakat bátran hasznosíthatják a gyakorlatokon. Egyértelmúen hátránya viszont az egy intézményhez való kötődés, a néhány szakvezetővel való munkakapcsolat, hogy a hallgatók nem tapasztalnak meg többféle „mintát”. Ezen segít a gyakorlati képzés utolsó két hónapja azzal, hogy a hallgatók összefüggő szakmai gyakorlatukat külső iskolákban végzik. Így megvalósul a képzésben a nyitottság, a rugalmasság, a sokszínüség a szakmai gyakorlatok vonatkozásában is.

\section{Az összefüggő komplex külső szakmai gyakorlatról}

A tanító szakos hallgatók képzésében a 3200 tanórából a 2007-ben végző évfolyamon 705 tanórát (22\%-ot) képvisel a gyakorlati képzés. Ebből a vizsgált nyolc hét külső összefüggő szakmai gyakorlatnak az órakerete 240 óra. A hallgatók a teljes képzésről szóló tájékoztató mellett külön dokumentumot (igazoló füzetet) vezetnek, vezettetnek maguknak a gyakorlati képzés elvégzéséről. Ebben a füzetben a gyakorlati képzés teljesítésének feltételei szerepelnek, és az elvégzett gyakorlatok igazolása is itt történik meg. Természetesen a féléveket lezáró értékelések már az indexbe kerülnek be. A hallgatók munkáját szakvezetöik rendszeresen véleményezik, a külső szakmai gyakorlatról pedig több dokumentumban is részletesen értékelik őket.

A külső szakmai gyakorlatot nyolc hét alatt teljesítik a hallgatók. Két-két hétig tanítanak egy-egy alsó tagozatos osztályban. Így a két hónap alatt mind a négy osztályban két hetet töltenek. Az alsós osztályokban végzett gyakorlattal párhuzamosan végzik müveltségterületi feladatukat az iskola 5-6. osztályában. A 240 órás gyakorlatból minimum 60 tanórát kell teljesíteni a hallgatóknak, amelyből minimum 10 müveltségterületi óra. A külső szakmai gyakorlatnak részei a hospitálások, előkészítések, elemzések, napközis foglalkozások, egyéb tevékenységek, programok, rendezvények is. A külső szakmai gyakorlatról 91 fö nappali tagozatos hallgatóról kapott visszajelzések alapján elmondható, hogy arányosan teljesítették tanóráikat az egyes osztályokban. 


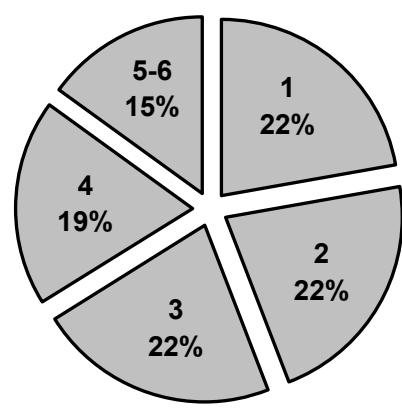

\section{1. ábra: Tanítási órák osztályonkénti megoszlása}

A hallgatók 55 különböző iskolában voltak gyakorlaton, 36 iskolában csak egy hallgató volt, 15 intézményben kettő vagy kettőnél is több. A külső szakmai gyakorlatot a hallgatók általában lakóhelyükön teljesítik, azonban többen Kaposváron maradnak. Ebben a tanévben a hallgatók 25\%-a, azaz minden negyedik hallgató Kaposváron volt. Legnagyobb arányban Somogy megyében (35\%) teljesítették külső gyakorlatukat, Tolnában, Baranyában, Zalában már kisebb arányban voltak a hallgatók. Amennyiben hazánk regionális megoszlását nézzük, elmondható, hogy a hallgatók mindössze 16\%-a teljesítette gyakorlatát a régión kívül. Ez egyben a szak beiskolázási területét is jól reprezentálja.

A hallgatók a szakmai gyakorlat alatt minden alsó tagozatos tantárgyat tanítanak. Érdemes egy pillanatra áttekintenünk, hogy hányféle megnevezés alatt történik a kerettantervben hivatalosan megnevezett tárgyak szerepeltetése.

\section{2. táblázat: Tantárgyak megnevezése}

\begin{tabular}{|l|l|l|}
\hline Sorszám & \multicolumn{1}{|c|}{$\begin{array}{c}\text { Tantárgy neve } \\
\text { a kerettantervben }\end{array}$} & \multicolumn{1}{c|}{$\begin{array}{c}\text { Tantárgy neve } \\
\text { a különbözö iskolákban }\end{array}$} \\
\hline 1. & magyar nyelv és irodalom & $\begin{array}{l}\text { magyar nyelv és irodalom, magyar } \\
\text { nyelv, magyar irodalom, nyelvtan, } \\
\text { olvasás, írás, fogalmazás }\end{array}$ \\
\hline 2. & matematika & matematika \\
\hline 3. & környezetismeret & környezetismeret, természetismeret \\
\hline 4. & ének-zene & ének-zene \\
\hline 5. & testnevelés és sport & testnevelés, testnevelés és sport \\
\hline 6. & technika és életvitel & technika, technika és életvitel \\
\hline 7. & rajz és vizuális kultúra & $\begin{array}{l}\text { rajz, rajz és vizuális kultúra, rajz } \\
\text { és vizuális nevelés }\end{array}$ \\
\hline
\end{tabular}


Természetesen lehetne mondani, hogy nem feltétlenül a megnevezésen múlik a tanulók oktatása-nevelése, hanem a tantárgyi tartalmakon. Ez valóban így van, de azért időnként árulkodnak a kissé formálisnak tekintett dolgok, szavak is arról, hogy mit tartunk fontosnak, lényegesnek, mely terület kap prioritást, mennyire komplexen kezelünk bizonyos területeket. Ebben a tanulmányban erre nem térünk ki részletesebben, hiszen a hallgatók gyakorlata mélyebb összefüggések feltárásához nem szolgáltatott elégséges információt.

Érdekes azonban áttekintenünk, hogy a felsorakoztatott hét tantárgy vonatkozásában milyen arányokat figyelhetünk meg a hallgatók képzésében, a gyakorlatukon, illetve a kerettantervben milyen arányban szerepelnek az alsó tagozaton.

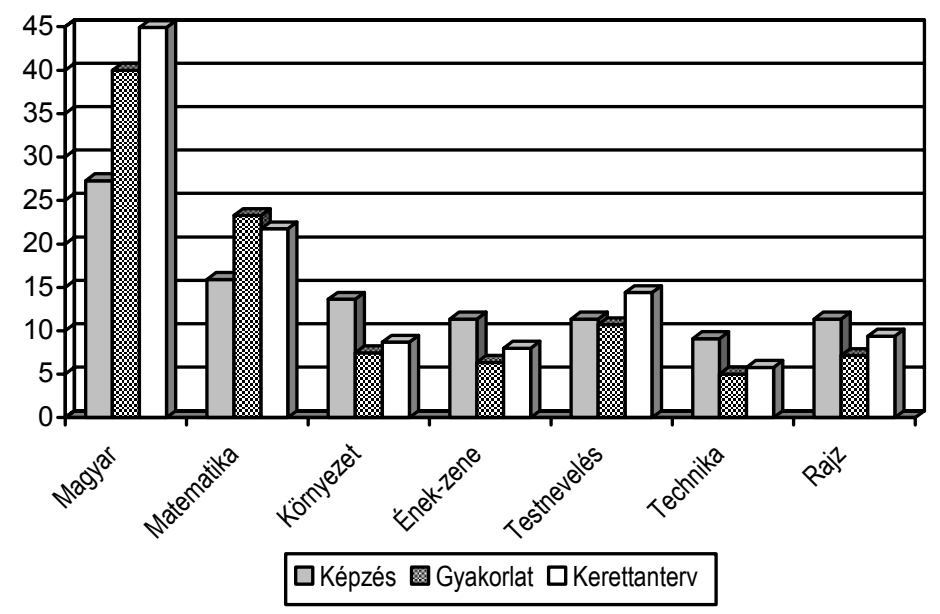

2. ábra: Tantárgyi arányok

Jól érzékelhető, hogy bizonyos területeken a hallgatók képzésében (környezetismeret, ének-zene, technika, rajz), másoknál pedig a kerettantervben (magyar, matematika, testnevelés) kapnak nagyobb hangsúlyt a tantárgyak. Ezt alapvetően azzal magyarázzuk, hogy a hallgatók korábbi - felsőoktatási képzését megelőző - tanulmányaiban is nagyobb felkészítést kaptak bizonyos területekből, míg más területeken több tanulással lesznek csak alkalmasak azon tárgyak oktatására. Szólhatnánk még azokról a kötelező érettségi tárgyakról, amelyek szintén a korábbi tanulmányukra való építkezés gondolatát erősítik (magyar, matematika).

Felmerül a kérdés, hogy a gyakorlaton milyen arányban teljesítik óráikat a hallgatók az egyes tantárgyakból. A 2. ábrából is leolvasható, hogy a szakvezetők nagymértékben a közoktatási arányoknak való megfelelést figyelembe véve jelölik ki az órákat, csak kicsit térnek el a tanulói tanórák arányától. A fóiskolai képzés oldaláról megfogalmazott tanórai arányokat is figyelembe véve elmondható, hogy 
egy területen magasabb a gyakorlat aránya (matematika), némileg kevesebb a gyakorlat aránya négy területen (technika, környezet, ének-zene, rajz), és két területen nagyobb ez a negatív eltérés (magyar, testnevelés). Ez természetes, hiszen nem a hallgatók tartották az összes tanórát, viszont arányaiban jól „leképezték” az iskolai tanórák arányait tanítási gyakorlatukon.

A kéthónapos szakmai gyakorlaton a hallgatók a tanórák mellett a tanulókkal való minden foglalkozásban részt vettek. Ezek érzékeltetésére álljon itt az alábbi felsorolás:

- farsang

- filmvetítés

- hospitálás

- $\quad$ kézmüves foglalkozás

- korrepetálás

- napközi

- rendezvények

- $\quad$ sportköri foglalkozás
- $\quad$ szabadidős foglalkozás

- $\quad$ szakkörök

- $\quad$ színházlátogatás

- tanulmányi versenyek

- tanulók étkeztetése

- tanulók kísérése

- ügyeletek

A tanulókkal való foglalkozások széles palettája mellett a tantestületi munkába is bekapcsolódtak. Különböző értekezleteken (munkaértekezlet, nevelési, nevelőtestületi, osztályozó) és továbbképzéseken (tankönyvkiadós, integrációs) vettek részt. Megismerkedtek a szülőkkel való kapcsolattartás különböző formáival is (családlátogatás, fogadóóra, szülői értekezlet, szülők-nevelők bálja).

Az összefüggő szakmai gyakorlatról az iskolák szöveges értékelést adtak le. Kétféle szempontrendszert követtek az intézmények.

\section{A változat}

- a hallgatók személyisége, egyénisége;

- felkészülése a tanítási órákra;

- kapcsolata, viszonya a gyermekekhez;

- kapcsolata a tanárokkal, a felnőttekkel;

- egyéb észrevételek.

\section{$B$ változat}

- a hallgató általános adatai;

- kapcsolatfelvétel, kommunikáció;

- munkához való viszony, felkészülés a tanórákra;

- óravezetés;

- $\quad$ tanórán kívüli tevékenység.

Átolvasva az értékeléseket, összességében elmondható, hogy nagyon nagy eltérést mutatnak terjedelemben, és ezzel összhangban tartalmukban is a szakvezetői vélemények. A legrövidebb értékelés mindössze hét soros volt, a legtöbb azonban az intézmény kérésének megfelelő terjedelemben (két oldal), és tartalommal készült. Ennek ellenére túl általánosak a megfogalmazások, így azok kevéssé hasznosíthatók a későbbi évfolyamokkal történő foglalkozásban. 
A tanórákra való felkészülés és azok vezetése tekintetében az alábbi jellemzők olvashatók ki a leadott értékelésekből:

- A hallgatók a tanórákra igényességgel készültek.

- Óratervezeteik ötletgazdagok, jól használhatók voltak.

- Megteremtették a szóbeli és írásbeli feladatok egyensúlyát.

- A tanórákon megvalósult a házi feladatok jó előkészítése.

- Elgondolkodtató, egyértelmü, szabatos kérdésfelvetés érvényesült a tanórákon.

- Módszertani ismereteik megbízhatóak.

- Pedagógiai felkészültségük alapos.

- Használatos módszereik változatosak, célratörök voltak, a didaktikai elveknek és tartalomnak megfeleltek.

- Szemléltetésükben figyelembe vették a tanulók életkori sajátosságait.

- A tanórák felépítésében megvalósult a fokozatosság elve.

- A tanulókkal való foglalkozás munkaformáit azonban hiányosan alkalmazták.

Külön kiemelték a hallgatók szakmai felkészültségét, amelyet így jellemeztek:

- Szakmai felkészültségük alapos, amely a leadott tervezetekben, a tanórák vezetésében egyaránt érvényesült.

- Tantárgyi koncentráció lehetőségeit kihasználták.

- Szakmai felkészültségük, olvasottságuk átlagos.

- Ismereteik megfelelőek, alaposak.

- Ismereteiket a gyakorlat alatt is bővítették.

A tanórákon kívüli hallgatói tevékenységekre kívánták felhívni figyelmünket a szakvezetők az alábbi gondolatokkal:

- Sok időt töltöttek a tanulókkal.

- Megismerték a tanulók egyéniségét, tantárgyakhoz való viszonyát.

- Tanórán kívüli programokon is aktívan jelen voltak.

A szöveges értékelésekben különös gonddal fogalmazták meg a szakvezetők a pedagógusi hivatás gyakorlásával összefüggő mutatókat:

- Személyisége: példamutató, tisztelettudó, lelkiismeretes, kommunikatív, segítőkész, szereti a tanulókat...

- Tanulókkal való kapcsolata: közvetlen, kedves, barátságos, határozott, derüs, kellemes, oldott légkört teremtő...

- Óravezetése: demokratikus, magabiztos, nyugodt, kiegyensúlyozott, türelmes...

- Pedagógiai érzéke: jól motivál, differenciál, folyamatosan figyeli az egyéni teljesítményeket, az érdeklődést...

A szöveges értékelés mellett a hallgatók osztályzatokat is kaptak. Mindegyik hónapban külön az általános és külön a müveltségterületi tanításukra, tevékenységükre. 


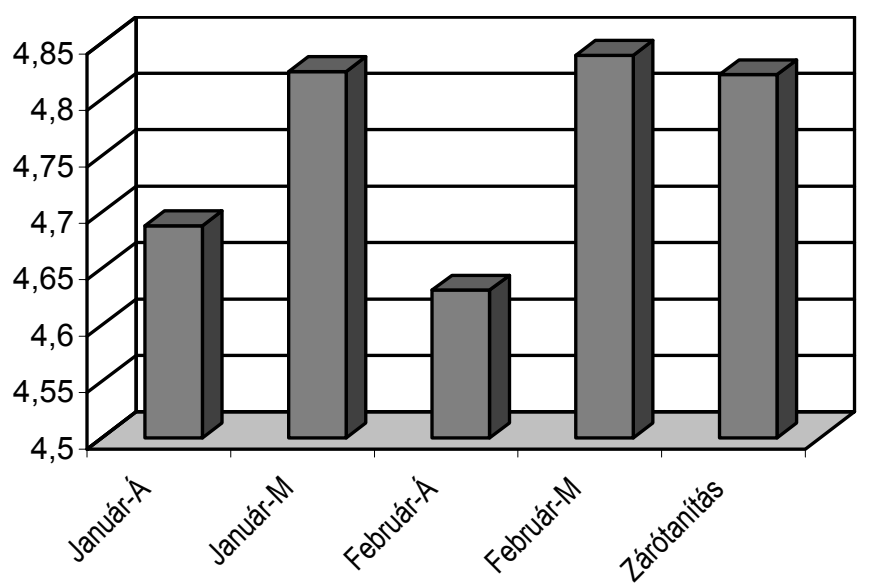

3. ábra: Hallgatói osztályzatok átlagai

Látható, hogy a hallgatók müveltségterületi értékelése, osztályzata kitünő, a saját érdeklődésüknek, tehetségüknek megfelelő területen rendkívük sikeresen szerepelnek. $\mathrm{Az}$ is öröm, hogy más tantárgyak, területek vonatkozásában is szép teljesítményt mutattak. Leggyengébb átlageredményt februárban, az általános tárgyakból teljesítették; a legjobb eredményt pedig a februári müveltségterületi tárgyakból érték el.

Összességében elmondható, hogy a hallgatói szakmai gyakorlat teljesítménye mögött komoly felkészülés van. Ekkor már a hallgatók sem engedhetik meg maguknak, hogy a tanórára kevésbé felkészülten (esetleg készületlenül) menjenek be. Átérzik, átélik munkájuk felelősségét, hogy most már rájuk figyel a sok kis gyermeki szempár. A tanulók tőlük várják, hogy bevezetik őket a „mindentudás birodalmába".

\section{A hallgatói zárótanítások tapasztalatai}

Intézményünkben hallgatóink zárótanításukat is a külső gyakorlat alatt teljesítik. A zárótanítás a záróvizsga része, amelyet bizottság elött abszolválnak. A bizottság tagjai között szerepelnek oktatók, szaktanácsadók, tanítók, szaktanárok, az iskolák vezetői. A hallgató a zárótanításra óratervezettel készül, amelyet az iskola a zárótanítás jegyzőkönyvével együtt megküld intézményünknek. A hallgatói óratervezetek nagyon igényes formában és tartalommal készülnek, sok esetben a szemléltető anyagokat is mellékelik. A zárótanítások, szakmai gyakorlatok dokumentumait a szaktanszékek tantárgypedagógusai átnézik, hogy a későbbi oktatói tevékenységbe beépítsék a tapasztalatokat. A zárótanítás értékelésében a müveltségterületi eredményekhez hasonlóan nagyon magas átlagos teljesítményt mutattak hallgatóink (lásd 3. ábra). 
A zárótanításokra általában a tanítási gyakorlat végén, februárban kerül sor. Ezzel is biztosítani szeretnénk, hogy minél felkészültebbek legyenek, amikor a tanító szak képzésének gyakorlatát lezáró zárótanításukat teljesítik.

A zárótanítás időpontja mellett további érdekes mutató az is, hogy milyen tantárgyból teljesítik azt. Ebben a tanévben véletlenszerü sorsolással dőlt el, hogy a hallgatók milyen tantárgyból tartják ezen órájukat. Kilenc terület szerepelt a tantárgyak sorában, azaz kilenc „tétel” közül egyet húztak. A konkrét óra tananyagát, osztályát már a gyakorlóhely adta meg. Tehát intézményünk a tantárgy megnevezését küldte meg az iskoláknak. A véletlenszerü sorsolás az alábbi megoszlást eredményezte a zárótanítás tantárgyai között.

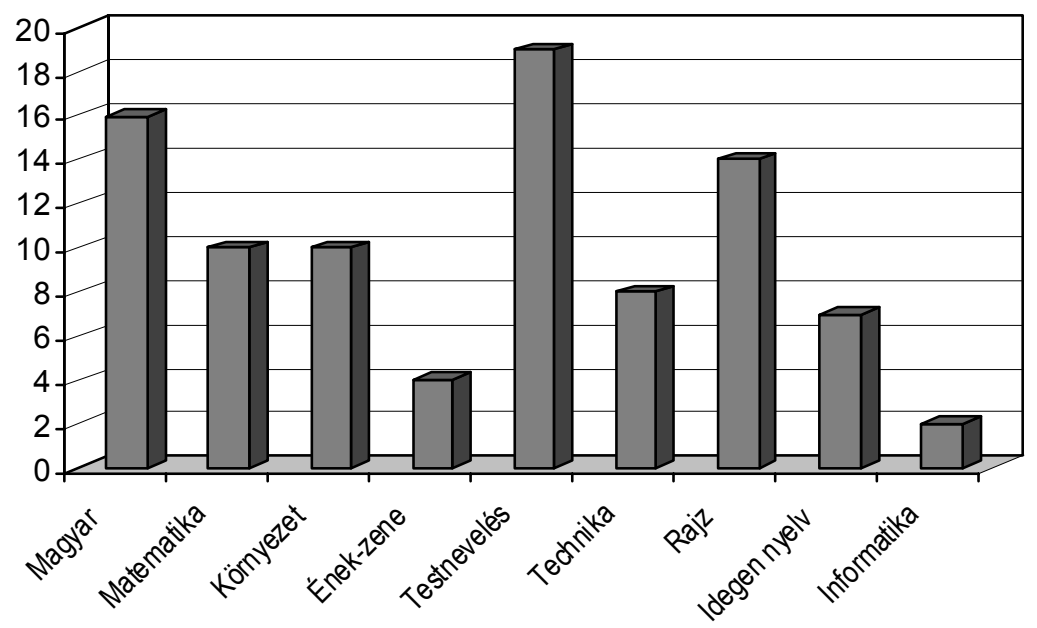

4. ábra: Zárótanítások tantárgyi megoszlása

\section{Szakvezetői vélemények egy kérdőív tükrében}

A képzés külső szakmai gyakorlata többek között alkalmas arra is, hogy a közoktatás igényeinek való megfelelést vizsgáljuk. Ehhez egy elégedettségi kérdőívet szerkesztettem, amelyet a külső szakvezetők töltöttek ki, és küldtek vissza számomra. A kérdőívben válaszadók egy ötös skálán értékelték az egyes állításokat, amelyek a következö területekre vonatkoztak:

- megfelelő képzés,

- jól hasznosítható ismeretek,

- korszerübb szaktárgyi ismeretek,

- elméleti és gyakorlati ismeretek,

- a pedagógus hivatás megalapozása,

- pedagógiai, pszichológiai tanulmányok, 
- szaktárgyi tanulmányok 1-4. o.,

- müveltségterületi tanulmányok 1-6. o.,

- oktatásszervezés,

- egyéb javaslatok.

A kérdőívekre adott válaszok átlagértékei alapján a visszaküldött száz kérdőív értékelése összesítve az 5. ábrán látható.

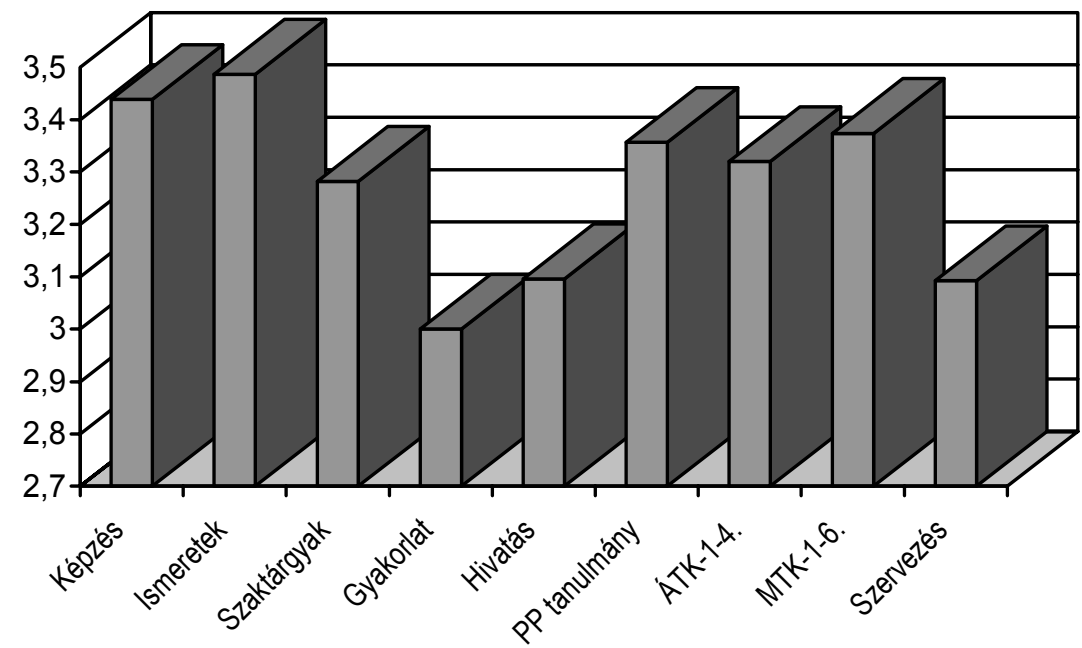

5. ábra: Szakvezetői vélemények

Három csoportot alkotva a pontozásos válaszokból megállapítható, hogy a legjobb eredményt a jól hasznosítható ismeretek, a megfelelö képzés és a müveltségterületi tanulmányokra kaptuk a szakvezetőktől. A középmezőnybe a pedagógiai, pszichológiai tanulmányok mellett a szaktárgyi tanulmányok és legkorszerübb ismereteik kerültek; legrosszabb pontértéket az oktatásszervezés, a pedagógushivatásra felkészítés és az elméleti ismeretek melletti gyakorlati felkészítés kapott. Így a jövőben ezeket a területeket javítani szükséges.

Az utolsó nyitott kérdésre - más kérdőívekhez hasonlóan - a szakvezetők mindössze 15\%-a válaszolt. Az alábbi felsorolás összegzi a válaszokat. Látható, hogy nagyon heterogén területeket érintenek a szakvezetők. Minden valószínüség szerint ennek ellenére érdemes átgondolni a felvetett témákat, hiszen nem feltétlenül csak a „válaszolóknál” jelentkezhettek azok.

A szakvezetők által - szó szerint idézve - az alábbi problémák kerültek felsorolásra:

- $\quad$ nincs idő a pedagógus szerepkörök megfigyelésére, gyakorlására;

- az alternatív tanulásszervezési módokról kevés ismerete van a hallgatóknak; 
- az aktuális oktatáspolitikáról, gyakorlati alkalmazásáról hiányosak ismereteik;

- a tanítási órákon kívül nehezen tudnak kapcsolatot teremteni a gyerekekkel;

- a kooperatív csoportmunkát nem ismerte a hallgatóm;

- a legújabb módszereket nem ismerte a hallgatóm;

- a modern technikát nem használta a hallgatóm.

A kérdőív kérdései csak egy szakvezetői „globális” véleményalkotásra adtak módot és lehetőséget. A jövőben szükséges lesz a szakvezetők differenciáltabb megkérdezésére. Azonban ezeket a tapasztalatokat is fel lehet használni a hallgatókkal való munka során, vagy egy következő kérdőív összeállításában. Módot és lehetőséget kaptak a szakvezetők a hallgatói értékelésekre a nyílt kérdéssel is, de csak kevesen éltek ezzel a lehetöséggel.

\section{Összegzés, ajánlás}

A külső szakmai gyakorlat dokumentumai, érdemjegyei és a kérdőív feldolgozása, elemzése, értékelése alapján megállapítható következtetések segítik az elkövetkezö évek szakmai munkájának fejlesztését. Az új alapszak képzésében meg kell ôrizni azokat a gyakorlati képzési kereteket, amelyek már a korábbi szakmai gyakorlatok alapján is bizonyították a tanítói hivatásra való felkészítés sikerességét.

A hallgatók továbbra is vegyenek részt minden osztályban a tanórai és tanórán kívüli munkában. Kapjanak lehetőséget 5-6. osztályban is a választott müveltségterületi képzésük kipróbálására, az iskolában szervezett ún. nem szakrendszerủ oktatásra.

Továbbra is érdemes fenntartani a hallgatók lakóhelyéhez köthető külső szakmai gyakorlatok helyszíneit, de a folyamatos fejlesztést szem elött tartva szükséges azokat szabályozni. Ebben az esetben a körültekintően elkészített, és kiadott dokumentumokban megfogalmazott elvárások helyszíni ellenőrzéséről is gondoskodni kell.

A hallgatók munkájának értékelését át kell tekinteni, hiszen egy sokkal differenciáltabb, az egyes részterületeket külön-külön is figyelembe vevő értékelési rendszert kell az iskolák szakvezetőinek rendelkezésére bocsátani. Így várható csak el a hallgatói szöveges értékelések hasznosítása a következő évfolyamok képzésében.

„Talán nem nehéz belátni azt sem, hogy a pedagógus presztízse szorosan öszszefügg a pedagógus gondolkodásáról, a pedagógiai tudásról vallott felfogással. Ha társadalmi méretekben elterjed az a hiedelem, hogy a pedagógiai tevékenység nem feltételez sajátos tudást, illetve, hogy a pedagógusok nem rendelkeznek egy olyan tudással, ami megkülönbözteti őket a laikusoktól, s aminek hatására a munkájukat eredményesebben tudják ellátni, ez óhatatlanul a szakma alábecsüléséhez vezet. Ha viszont bebizonyosodik, hogy van egy jelentős tudáskészlet, amit a pedagógusok birtokolnak, s amelyik eredményes, akkor ez megnöveli a pedagógusok autonómiáját mind az iskolafenntartókkal, az oktatáspolitikával, mind pedig a szülőkkel, a társadalommal szemben." (Falus, 2001. 214. o.) 
Napjainkban egyre több szó esik ennek a presztízsnek a visszaállításáról. A hallgatói külső szakmai gyakorlatok jó színterei lehetnek a felsőoktatás és a közoktatás párbeszédének az új tudás társadalma felé vezető úton.

\section{Irodalom}

158/1994. (XI. 17.) Korm. rendelet a tanító, a konduktor-tanító és az óvodapedagógus alapképzésben a képesítési követelményekről. 1. számú melléklet: A tanító szak képesítési követelményei.

77/2002. (IV. 13.) Korm. rendelet a felsőoktatási alapképzési szakok képesítési követelményeinek kreditrendszerü képzéshez illeszkedő kiegészítéséről. 13. számú melléklet.

252/2004. (VII. 30.) Korm. rendelet a többciklusú, lineáris felsőoktatási képzési szerkezet bevezetésének egyes szabályairól és az első képzési ciklus indításának feltételeiröl.

Falus Iván (2001): Gondolkodás és cselekvés a pedagógus tevékenységében. In: Báthory Zoltán - Falus Iván (szerk.): Tanulmányok a neveléstudomány köréböl. Osiris Kiadó, Budapest, 213-234. 